\title{
Fungal Diversity and Physicochemical Changes in Fresh Fruits During Storage at Ambient Room Conditions
}

\author{
Sahib Alam ${ }^{1}$, Shima Bibi, Murad Ali ${ }^{2}$ \\ ${ }^{1}$ Department of Agricultural Chemistry, The University of Agriculture, Peshawar 25130, Pakistan \\ ${ }^{2}$ Centre for Biotechnology and Microbiology, University of Swat, Pakistan \\ Email: dralam@aup.edu.pk
}

\begin{abstract}
The study aimed to investigate the effect of short-term postharvest storage on the fungal diversity and physicochemical and sensory quality of fresh fruits viz. apple, banana, grapes, guava and mango. The fruits were stored at ambient room temperature $\left(28^{\circ} \mathrm{C}\right)$ and evaluated for fungal diversity, total fungal and bacterial counts, moisture content, water activity $\left(\mathrm{a}_{w}\right)$, vitamin $\mathrm{C}$ content and sensory characteristics such as appearance, odour, taste, texture and overall acceptability at the initial ( 0 day), 7 and 14 days of storage. The dominant fungal genera isolated from all the fruits were Aspergillus niger (35.38\%), Penicillium spp. (28.24\%), Rhizopus stolonifer (25.35\%) and Aspergillus flavus (21.35\%) after 14 days of storage. Both the total fungal and bacterial counts increased significantly over storage time. However, the percent moisture content and $\mathrm{a}_{w}$ level of all the fruits decreased significantly $(P<0.05)$ after 14 days storage. The storage time did not significantly $(P>0.05)$ affect the vitamin $C$ content of fruits. Regarding sensory quality, apple got the highest score for appearance, odour, taste, texture, and overall acceptability followed by grapes whereas banana and guava got the lowest score for overall acceptability after 14 days storage. It was concluded that, at ambient room temperature a diversity of fungal species attacks fresh fruits and their shelf life, nutritional and sensory quality start deteriorating as early as after 3 days of storage.
\end{abstract}

Key Words: fruits, sensory characteristics, quality, microbial count, storage

\section{Introduction}

Fruits are amongst the first food items known to human beings. In fact, they have been in existence since the inception of mankind. Fruits, whether fresh or dried, have always formed a part of the staple diet of human beings. They are rich in nutrients and provide some of the essential minerals and vitamins to our body ${ }^{[1]}$. Apart from that, they also help in curing a number of diseases, for example, people who eat more fruits and vegetables are likely to have a reduced risk of some chronic diseases ${ }^{[2,3]}$.

Pakistan is blessed with diverse agro-ecological conditions, which favor the production of a great variety of fruits. Among them, mango (Magnifera indica) has a prominent position in Pakistan ${ }^{[4]}$. Mango is a rich source of essential nutrients and contains $83.3 \%$ water, $17 \%$ carbohydrates, $0.6 \%$ fiber, $0.6 \%$ ash and $37 \mathrm{mg} / 100 \mathrm{~g}$ vitamin $\mathrm{C}^{[5,6]}$. Apple (Malus domestica) is well characterized for its taste, flavor and dietary values all over the world. It is cultivated more or less everywhere in Pakistan ${ }^{[7]}$. Fresh apples contain $84.7 \%$ water, $13.9 \%$ carbohydrates, $0.8 \%$ fiber, $0.4 \%$ protein, $0.3 \%$ lipid, $0.3 \%$ ash and $8 \mathrm{mg} / 100 \mathrm{~g}$ vitamin $\mathrm{C}^{[8]}$. Banana (Musa paradisiaca) is long thick-skinned edible fruit that is yellow when ripe. One fresh medium sized banana contains $1.29 \mathrm{~g}$ of protein, $25.2 \mathrm{~g}$ carbohydrates, $0.4 \mathrm{~g}$ lipids, $0.5 \mathrm{~g}$ dietary fiber, $0.8 \mathrm{~g}$ ash and $7 \mathrm{mg}$ of vitamin $\mathrm{C}^{[6,8]}$. Grapes (Vitis vinifera), the non-climacteric fruit, grows on the perennial and deciduous woody vines of the genus Vitis. Fresh grapes contain water $80.8 \mathrm{~g}$, carbohydrates $17.5 \mathrm{~g}$, fiber $1.9 \mathrm{~g}$, protein $0.5 \mathrm{~g}$, lipids $0.3 \mathrm{~g}$, ash $0.6 \mathrm{~g}$ and vitamin C $4 \mathrm{mg}$ per $100 \mathrm{~g}$ of edible portion ${ }^{[6,8]}$. Guava (Psidium guajava) is cultivated more or less everywhere in Pakistan ${ }^{[9]}$. Therefore, it is one of the major fruits in Pakistan. Fresh guava contains about $83.3 \%$ moisture, $15 \%$ carbohydrates, $5.3 \%$ fiber, $1 \%$ protein, $0.4 \%$ lipid, $0.6 \%$ ash and $210 \mathrm{mg} / 100 \mathrm{~g}$ vitamin $\mathrm{C}^{[8]}$. 
Water is an essential constituent of fruits and vegetables. Most of the fruits have $80-90 \%$ water on fresh weight basis ${ }^{[10]}$. It exists in foods in free and bound states. The free water is expressed as water activity $\left(\mathrm{a}_{w}\right)$ of the sample. Fresh fruit, which contain high water content, have relatively low storage life ${ }^{[1]}$. Water activity $\left(\mathrm{a}_{\mathrm{w}}\right)$ affects the shelf life, texture, flavour, smell and overall acceptability of foods. In addition to influencing microbial spoilage, water activity also plays a significant role in determining the activity of enzymes and vitamins in foods and can have a substantial impact on their colour, taste, and aroma ${ }^{[12,13]}$.

In remote and especially fruit deficient areas of Pakistan, people intermittently obtain fruits and store them in open house system for daily consumption. The fruits are directly purchased from local markets or fruit orchards for further utilization for extended period of time. The consumers keep them in their houses at ambient room temperature $\left(\sim 25^{\circ} \mathrm{C}\right)$ in open containers for everyday consumption. The room temperature may increase as high as $35^{\circ} \mathrm{C}$ during the hot summer season. There is a real chance of quality deterioration because of the perishable nature of fruits. Warm climate, long postharvest storage and high humidity favor molds growth and reduction in nutritional and sensory quality of fruits ${ }^{[14,15,16 \text {, }}$

${ }^{17]}$. The objectives of this study were to assess the diversity of fungal flora that harbor the fruits during post-harvest storage and to analyze physicochemical and organoleptic changes in commonly consumed fruits of Khyber Pakhtunkhwa province of Pakistan over a two weeks period of time.

\section{Materials and methods}

\subsection{Collection of fruit samples}

Composite samples each of apple (Golden Delicious cv.), banana (Basarai cv.), grapes (King Ruby cv.), guava (Allahabadi cv.) and mango (Chaunsa cv.) fruits were collected in the late summer season (September-October) from the wholesale fruit market of Peshawar, Khyber Pakhtunkhwa, Pakistan.

\subsection{Storage of samples}

Six kilograms laboratory samples of each fruit type were stored in plastic fruit baskets at ambient room conditions (temperature $\sim 25^{\circ} \mathrm{C}$; relative humidity $67-72 \%$ and uniform air circulation). Three replicate baskets (each containing 2 $\mathrm{kg}$ fruit) were used for each fruit type thus making a total of 15 replicates. The baskets were covered with linen clothes to prevent external contamination. At 7 days interval, the fruit samples were evaluated for total fungal and bacterial counts, moisture content, water activity, vitamin $\mathrm{C}$ content and sensory attributes such as appearance, odour, taste, texture and overall acceptability at the start (i.e. 0 day), 7 and 14 days of storage. The fruit samples were also investigated for fungal diversity on the 14th day of storage.

\subsection{Microbiological evaluation of fruits}

\subsubsection{Total fungal count (TFC) and isolation and identification of dominant genera of fungi}

Total Fungal Count (TFC) was determined by using V8 media ( $175 \mathrm{ml} \mathrm{V8} \mathrm{vegetable} \mathrm{juice} \mathrm{(Cambell),} 3 \mathrm{~g} \mathrm{CaCO}_{3}, 0.01 \mathrm{~g}$ $\mathrm{ZnSO}_{4} \cdot 7 \mathrm{H}_{2} \mathrm{O}, 0.005 \mathrm{~g} \mathrm{CuSO} \square \cdot 5 \mathrm{H} \square \mathrm{O}, 0.05 \mathrm{~g}$ chloramphenicol, $20 \mathrm{~g}$ agar and distilled water $825 \mathrm{ml}$ ) by dilution plate method as described by ${ }^{[18]}$. Briefly, accurately weighed $1 \mathrm{~g}$ sample of the fruit was blended in $10 \mathrm{ml}$ sterilized distilled water in a glass universal bottle. One millilitre of the suspension was transferred to $9 \mathrm{ml}$ sterilized distilled water taken in another glass universal bottle and the process was repeated to obtain a final $10^{-3}$ times dilution of the sample. From this dilution, an aliquot of $100 \mu \mathrm{l}$ was transferred to V8 media plates and the Petri dishes were incubated at $28^{\circ} \mathrm{C}$ for 7 days. At the end of incubation period the total fungal counts were calculated. The dominant fungal genera were identified by cultural and morphological traits such as pattern of colony growth, conidial morphology and pigmentation. The identification was accomplished by placing a drop of lactophenol stain on a clean slide and then a small portion of the aerial mycelia of the isolated fungal strain was transferred to it with the help of a mounting needle. After spreading, a cover slip was gently placed over it and the slide was mounted and viewed under light microscope with high magnification lenses. The morphological attributes and appearances of the fungal strains were identified using fungal identification keys ${ }^{[19,20]}$.

\subsubsection{Total bacterial count (TBC)}

TBC was determined by the procedure as described by Andrew ${ }^{[21]}$ using V8 Agar media without chloramphenicol. Procedure for serial dilution of the sample and inoculation on media was essentially the same as was discussed for total fungal counts. The media plates were incubated at room temperature $\left(25-30^{\circ} \mathrm{C}\right)$ for 7 days. At the end of incubation time the total bacterial count of each sample was calculated.

\subsection{Physicochemical analysis of fruits}

\subsubsection{Moisture content}

Percent moisture content of the fruits was determined by oven drying method of Ranganna ${ }^{[22]}$. Accurately weighed $2 \mathrm{~g}$ 
fruit sample was taken in a clean dry Porcelain dish and dried in oven at $105^{\circ} \mathrm{C}$ for $5 \mathrm{~h}$ until constant weight was obtained. The loss in weight was recorded as the moisture content of the sample.

\subsubsection{Water activity}

Water activity of the samples was determined by the method described by ${ }^{[23]}$ and ${ }^{[24]}$ using a Novasina Thermoconstanter TH200 (Axaid Ltd., Pfaffikon, Switzerland).

\subsubsection{Vitamin $C$ content}

Vitamin C content of the fruit sample was determined by the method described by Ruck ${ }^{[25]}$. A $30 \mathrm{~g}$ edible portion of homogenized sample was blended with $100 \mathrm{ml}$ of $0.4 \%$ oxalic acid for $2 \mathrm{~min}$ in a Waring blender. The blended mixture was made to $500 \mathrm{ml}$ with $0.4 \%$ oxalic acid and was filtered; $20 \mathrm{ml}$ of the filtrate was titrated with standard 2, 6-dichlorophenol indophenol. Results were expressed as mg per $100 \mathrm{~g}$ wet basis.

\subsection{Sensory evaluation}

A panel of six adult volunteers with prior experience in sensory testing underwent sensory training to evaluate the quality attributes of the fruit samples using a 9-point hedonic scale (1 extremely disliked, 9 extremely liked). The fruit samples were then evaluated by the judges for appearance, odour, taste, texture and overall acceptability by the method as reported by Larmond ${ }^{[26]}$.

\subsection{Statistical analysis}

The data were analyzed by the analysis of variance (ANOVA) using two factors completely randomized (CR) design. All the analyses were carried out by statistical software package Minitab 16. Means were separated by Least Significant Difference (LSD) test ${ }^{[27]}$. Each mean was calculated from triplicate values.

\section{Results and discussion}

\subsection{Fungal diversity of fruits during storage}

Mycological survey of the fruit samples after 14 days of storage at ambient room temperature of $28^{\circ} \mathrm{C}$ showed the presence of 17 genera of fungi (Figure 1). Aspergillus niger was the most frequent mold (35.38\%) of all the mycoflora isolated from all the selected types of fruits. The other fungal genera that were predominantly present in the fruits included Penicillium spp (28.24\%) followed by Rhizophus spp (25.35\%), A. flavus (21.35\%), Fusarium spp (12.34\%) and Yeasts (11.35\%). The lowest occurrence frequency $(0.53 \%)$ was exhibited by Plasmopara viticola which was mostly isolated from grapes. The present results are supported by the previous work done by ${ }^{[28][29]}$ and ${ }^{[30]}$ who isolated similar fungal species from various fruits.

Micro-organisms, especially fungi, are known to destroy fruits, thereby reducing the quality and quantity for consumption and the profits obtained from sales of fruits. Due to active metabolism, fruits are prone to brisk deterioration during storage ${ }^{[31]}$. In addition, the high concentration of sugars, minerals, amino acids, vitamins and low $\mathrm{pH}$ of fruits further facilitate fungal infestation and spoilage during storage ${ }^{[32]}$. Likewise, the processes such as harvesting, storing, packaging and transportation may cause physical injury that result in post-harvest loss and fungal spoilage of fruit. Unhygienic market conditions and poor handling practices further aggravate microbial spoilage of fruits. It has been reported that $30-40 \%$ of fruits and vegetables produced worldwide are lost due to spoilage especially during post-harvest stages ${ }^{[33]}$. This has been associated with spoilage fungi which can be toxigenic or pathogenic ${ }^{[34]}$.

A diversity of fungal species were isolated from selected fruits during the current study. Out of these species $A$. niger which causes black mold disease on certain fruits and produce ochratoxins had the highest frequency (35.38\%), followed by Penicillium spp (28.24\%), Rhizophus spp (25.35\%) and A. flavus (21.35\%). All these species play active role in deterioration of food and feed system. Isolation of toxin-producing fungi such as Aspergillus spp. and Fusarium spp. from fruits during our study warrants the need for regular monitoring and maintaining proper hygienic conditions during storage to safeguard the consumers from mycotoxins and other toxic metabolites which can be harmful to humans and animals. $R$. stolonifer is a significant agent of fruit diseases. It depends on sugar or starch for its source of carbon substances and uses food matter, mostly soft fruits, like grapes or strawberries for growth, nutrition and reproduction. Similarly, F. oxysporum which was mostly isolated from banana in the current study, produce potentially toxic mycotoxins such as fumonisins, zearalenone and trichothecenes. However, Penicillium species which are widely distributed in the environment are often considered non-pathogenic to humans ${ }^{[30]}$ 


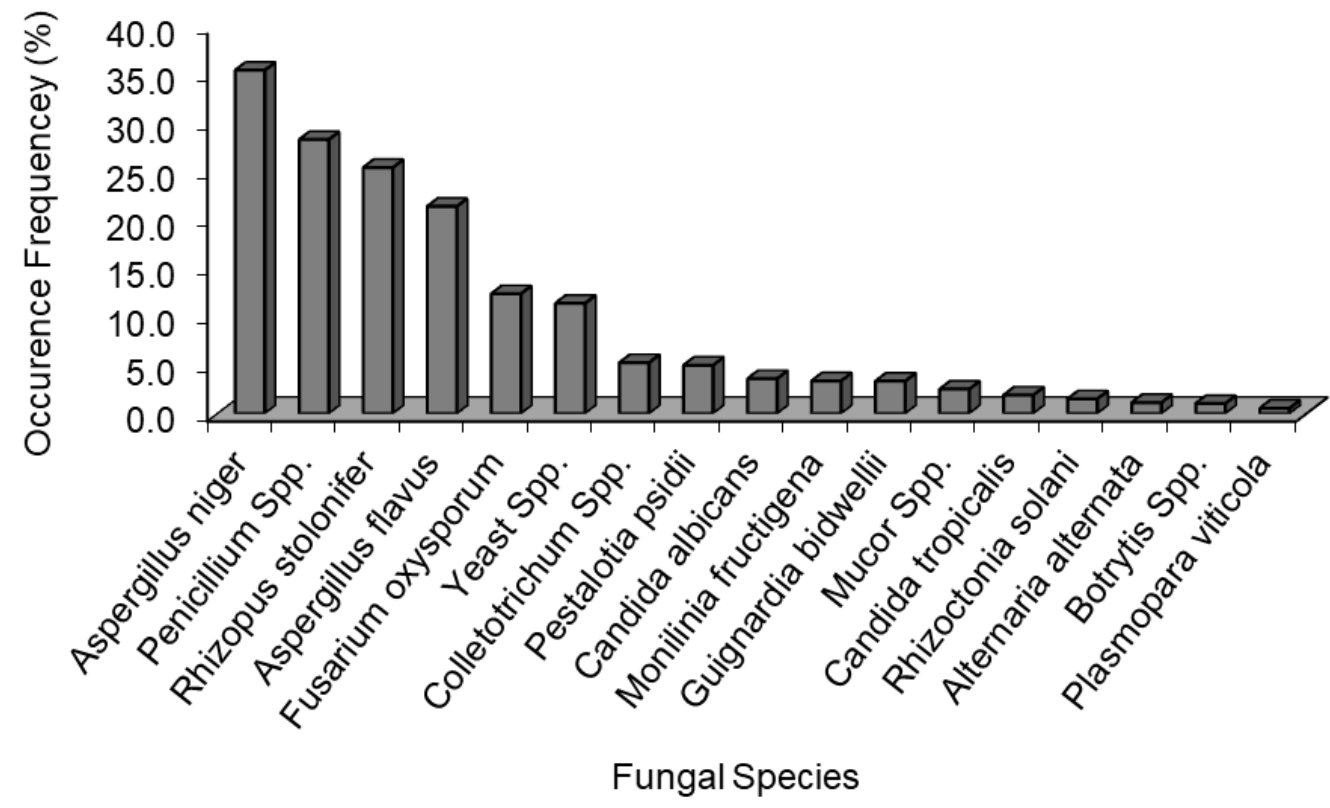

Figure 1. Frequency of occurrence (\%) of different fungal species in apple, banana, grapes, guava and mango fruits after 14 days storage at ambient room conditions

\subsection{Total fungal and bacterial count}

The data regarding total viable fungal counts of apple, banana, grapes and mango fruits stored at ambient room condition for 14 days showed that the fungal population in all fruits significantly increased over time (Figure 2). The total viable fungal counts of apple, banana, grapes, guava and mango increased from $2.01 \times 10^{3}$ to $3.84 \times 10^{3}, 3.27 \times 10^{3}$ to 3.60 $\times 10^{3}, 3.47 \times 10^{3}$ to $4.34 \times 10^{3}, 2.01 \times 10^{3}$ to $4.21 \times 10^{3}$ and $3.01 \times 10^{3}$ to $4.05 \times 10^{3} \mathrm{CFUs} / \mathrm{g}$, respectively over the storage period. Maximum increase was observed in guava while minimum in banana during the storage period. The results of the present study are in line with those reported by ${ }^{[35]}$. The results for total bacterial count of apple, banana, grapes, guava and mango also showed similar pattern of results (Figure 3). Both the fruit type and storage time had significant effects on the total viable bacterial counts (Table 1). The maximum increase in TBC was observed in mango while the minimum in apple over 14 days of storage. The highest bacterial count $\left(6.63 \times 10^{3} \mathrm{CFUs} / \mathrm{g}\right)$ was recorded in banana after a storage period of 14 days. Similar results were previously reported by ${ }^{[36]}$.

A number of factors are involved in the microbial contamination of fruits. The pre-harvest factors include use of partially treated manure, irrigation with livestock-used farm ponds or storage near roosting birds ${ }^{[37]}$. Improper or harsh handling is the most notable postharvest factor which causes skin breaks, bruises or lesion leading to increased chances of microbial contamination of fruits. Normal microflora of fruits includes bacteria, yeast and moulds. These microbes either remain adhered to the outer skin of fruits or deeply penetrate the edible portion by microscopic spores. Higher $\mathrm{a}_{\mathrm{w}}$, high sugar content and more acidic $\mathrm{pH}(<4.4)$ of fresh fruits promote the growth of xerotolerant fungi or osmophilic yeast ${ }^{[38,39]}$. 


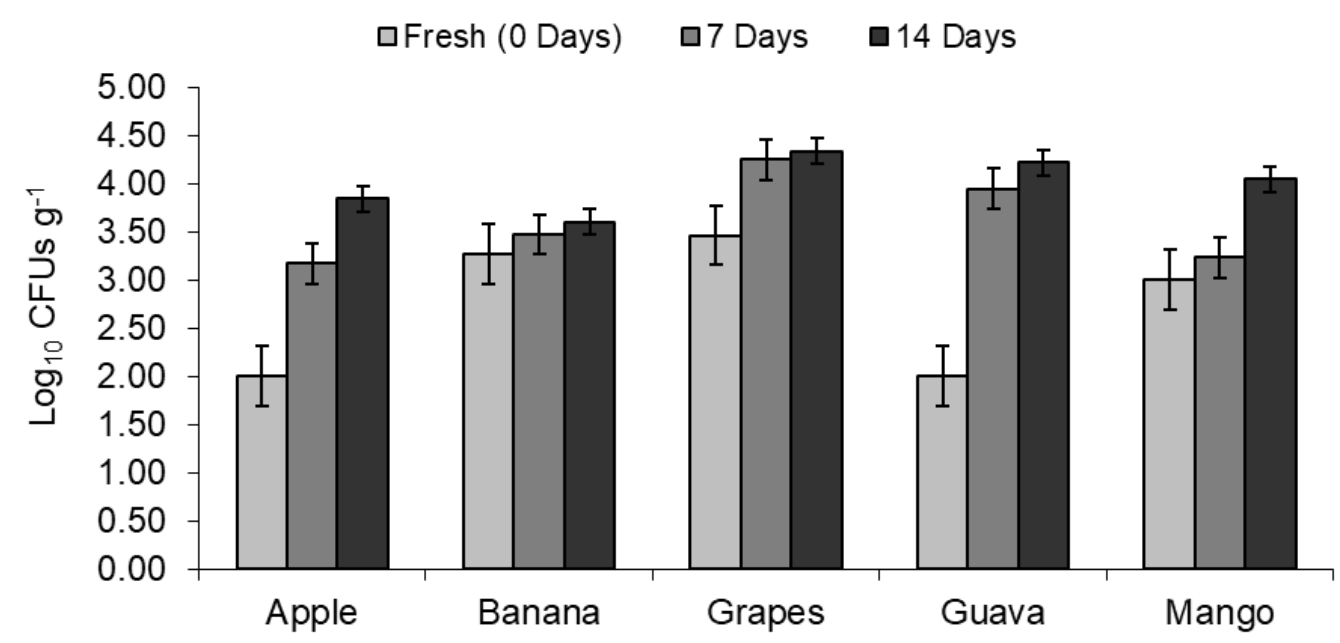

Figure 2. Total fungal count (CFUs $\left.x 10^{3} / g\right)$ of apple, banana, grape, guava and mango fruits samples during 14 days storage. The bars represent the standard errors of means

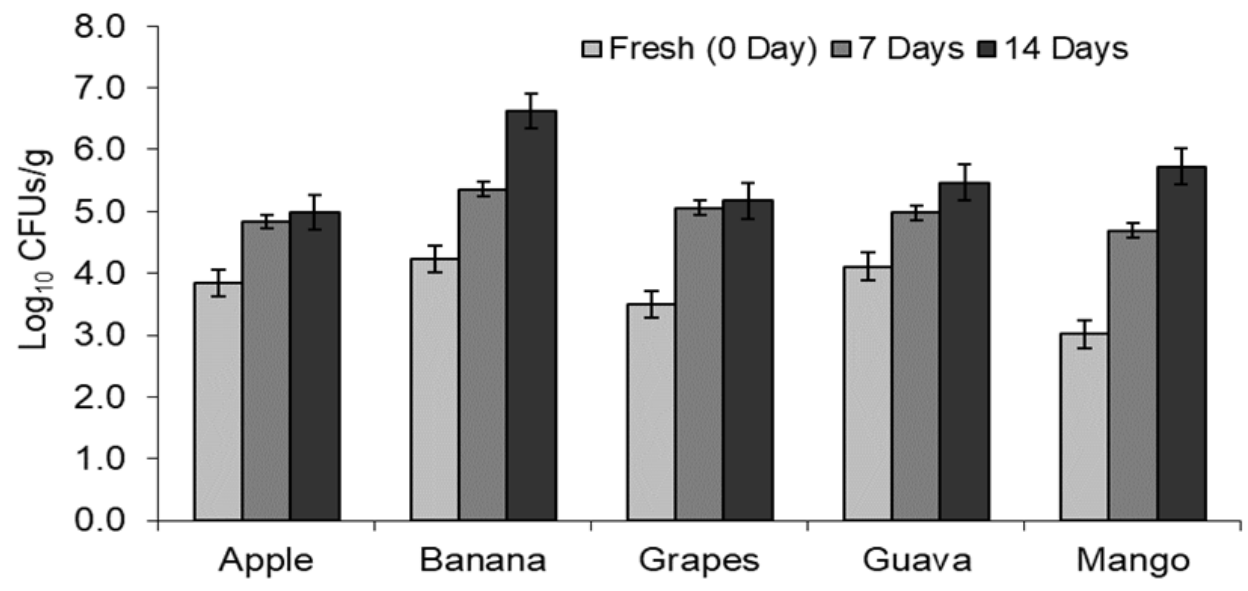

Figure 3. Total Bacterial Count (CFUs $\times 10^{3} / \mathrm{g}$ ) of apple, banana, grape, guava and mango fruits samples during 14 days storage. The bars represent the standard errors of means

\subsection{Moisture content}

The moisture content of selected fruits was significantly $(P<0.05)$ affected by the fruit type as well as storage time (Table 1). Highest moisture content $(86.70 \%)$ was recorded in fresh grapes, which progressively decreased to $74.58 \%$ after 14 days storage (Figure. 4). The lowest level of moisture $(69.18 \%)$ was examined in guava fruit after 14 days of storage. It was observed that the moisture content of all fruits significantly $(P<0.05)$ reduced over two weeks period of storage time. These results are in agreement with ${ }^{[5]}$ who observed a gradual decrease in the moisture content of fruits with storage time. 


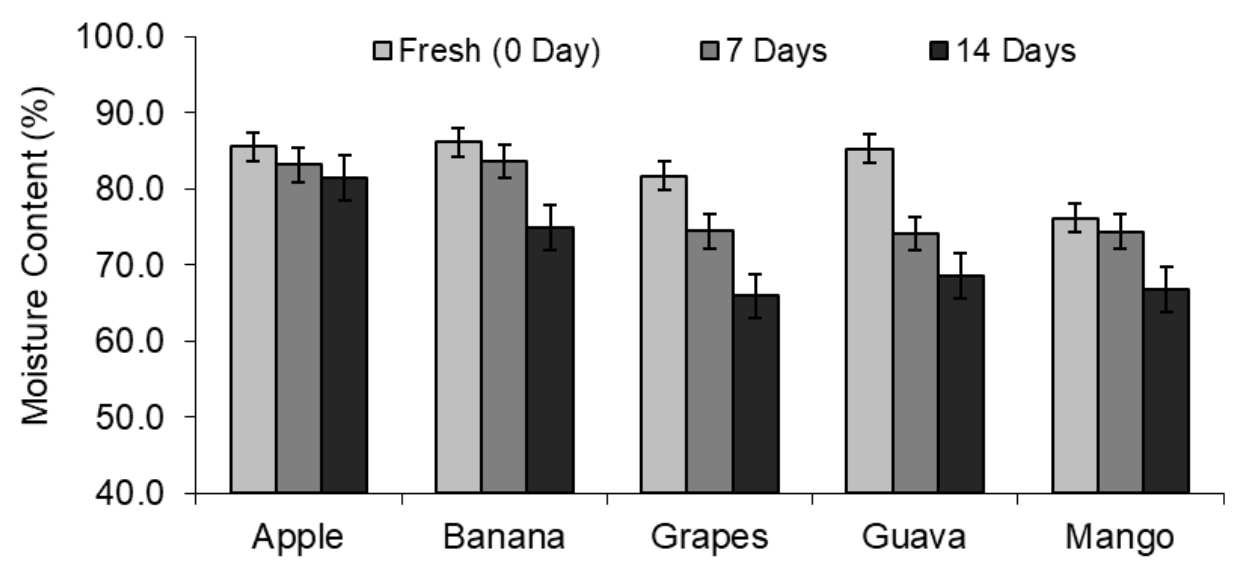

Figure 4. Moisture content (\%) of apple, banana, grape, guava and mango fruits samples during 14 days storage at ambient room temperature. The bars represent the standard errors of means

Fresh produce continues to lose water after harvest ${ }^{[40]}$. Fruits are the living parts of the plant and contain 70 to $95 \%$ water. When food and water reserves are exhausted, produce dies and decays. Thus, to extend storage life, the rate of water loss must be minimized ${ }^{[4]]}$. Fruits must, therefore, be kept in a moist atmosphere ${ }^{[42]}$, but, on the other hand, extended storage under humid and warm conditions facilitates the attack of fungi and bacteria. Deep penetration of decay makes infected fruit unusable. This is often the result of contamination of the produce in the field before harvest ${ }^{[41]}$. Quality loss occurs when the disease affects the fruits ${ }^{[43]}$. Therefore, it is imperative to store the fruits in controlled conditions of humidity and temperature to prevent the quality degradation and postharvest losses.

\subsection{Water activity}

Results regarding $\mathrm{a}_{w}$ of the fruits showed significant $(P<0.05)$ variations among the fruits types as well as storage intervals (Table 1). Water activity levels of all fruits exhibited a decreasing trend with increasing storage time (Figure. 5). The highest reduction was observed in mango, while the lowest in banana and apple fruits. The values of $\mathrm{a}_{w}$ examined in our study were pretty in line with those reported by ${ }^{[44]}$ and ${ }^{[45]}$ who observed $\mathrm{a}_{w}$ in the range of $0.970-0.996$ in fruits, vegetables and meat. The decrease in water activity of fruits with storage time was attributed to the loss of water by natural drying process.

Water activity describes quality and represents how much water is available and is ready to be used. It affects the shelf life, texture, flavor, smell and overall acceptability of foods. Water activity determines the lower limit of available water for microbial growth ${ }^{[13]}$. It is one of the key factors, which affect the activity of enzymes ${ }^{[24]}$ and have a substantial impact on the color, taste, and aroma of food ${ }^{[12]}$. Water activity is the most relevant parameter when considering moisture in relation to fungal growth. It is a prime tool practiced for care and increasing shelf life of food and feed with respect to physicochemical properties, speed of degradative reactions and microbial growth ${ }^{[46]}$. Water activity represents the free water content that is not physically or chemically bound to the substrate and is therefore instantly available for microbial growth. Fungal growth is therefore directly related to water activity rather than water content $p e r s e^{[46]}$. 


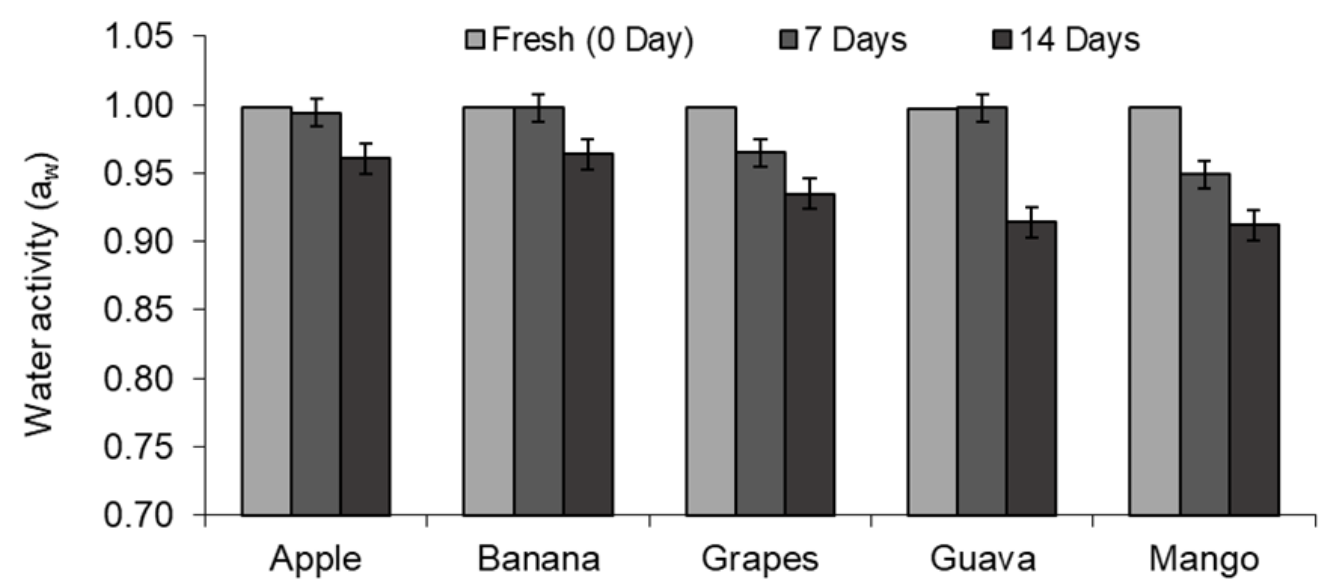

Figure 5. Water activity $\left(a_{w}\right)$ of apple, banana, grape, guava and mango fruits samples during 14 days storage at ambient room temperature. The bars represent the standard errors of means

\subsection{Vitamin C content}

A significant difference was noted in the vitamin $\mathrm{C}$ contents of the fruits (Table 1). The lowest amount of vitamin $\mathrm{C}$ was noted in grapes whereas the highest amount was observed in guava fruit (Figure 6). Except guava, a gradual but non-significant $(P<0.05)$ decrease in the vitamin $\mathrm{C}$ content of the fruits was noted during the storage period. The slight increase in vitamin $\mathrm{C}$ content of guava during storage might be due to the conversion of sugars into ascorbate especially by the D-galacturonate pathway for which the degradation of cell wall pectin can provide the substrate ${ }^{[48]}$. This pathway is especially active during the ripening stages of fruits. The increase in ascorbate during ripening is correlated with changes in the activity of enzymes affecting the redox state of the fruit during the breaker stage ${ }^{[49]}$. However, the overall results of the present study are fairly supported by the previous work done by ${ }^{[6,9,50]}$. During fruit storage, the vitamin $\mathrm{C}$ content is generally decreasing, but the losses are slower when the storage temperature is low. Ali et al. ${ }^{[1]}$ reported a marked decrease in the vitamin $\mathrm{C}$ content of apple during 6 weeks storage at ambient room temperature. In another study Jamba and Carabulea ${ }^{[52]}$ observed vitamin $\mathrm{C}$ content loss at the rate of $10-20 \%$ in apples during storage at controlled atmospheric conditions.

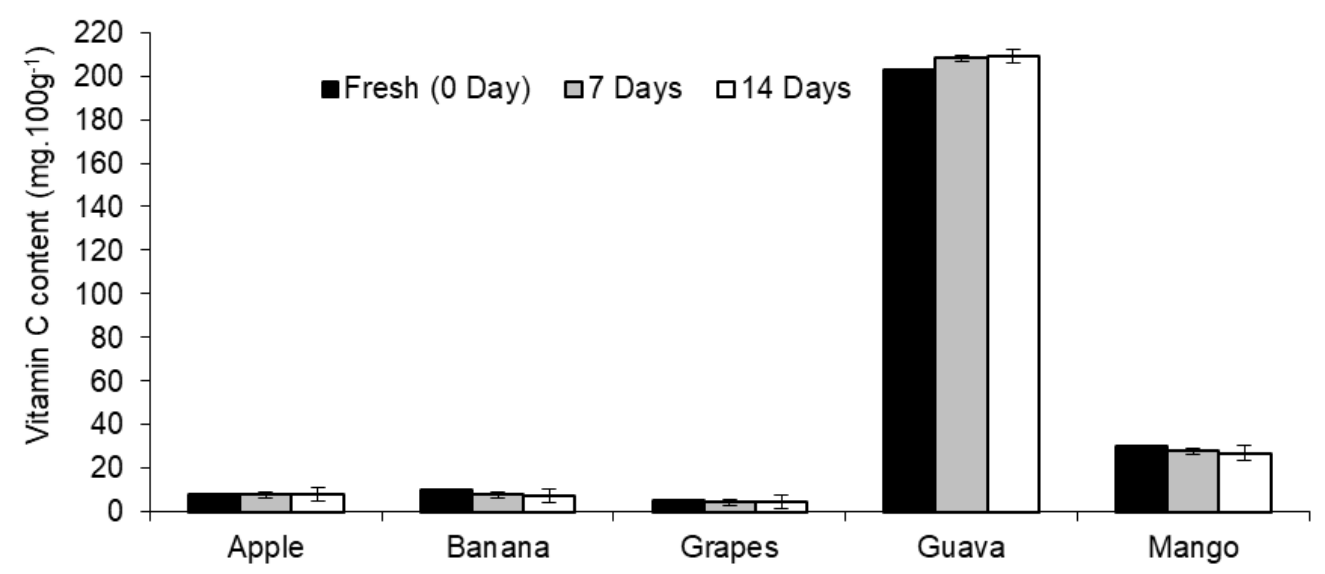

Figure 6. Vitamin $\mathrm{C}$ content (mg/100g) of apple, banana, grapes, guava and mango fruits samples for 14 days storage at ambient room temperature. The bars represent the standard errors of means

\subsection{Sensory evaluation}

\subsubsection{Appearance}

The results for appearance of apple, banana, grapes, guava and mango at 0,7 and 14 days of storage showed significant changes during the storage time (Table 1). Apple fruit was the most stable and banana was the least stable in appearance among the selected fruits (Figure 7). However, the appearance of all fruits was disliked gradually by the panel of judges with the passage of time. Similar results have been previously reported by ${ }^{[4]}$. The loss in appearance may be due 
to the loss in water which in turn resulted in the loss of overall quality of the fruits ${ }^{[7]}$.

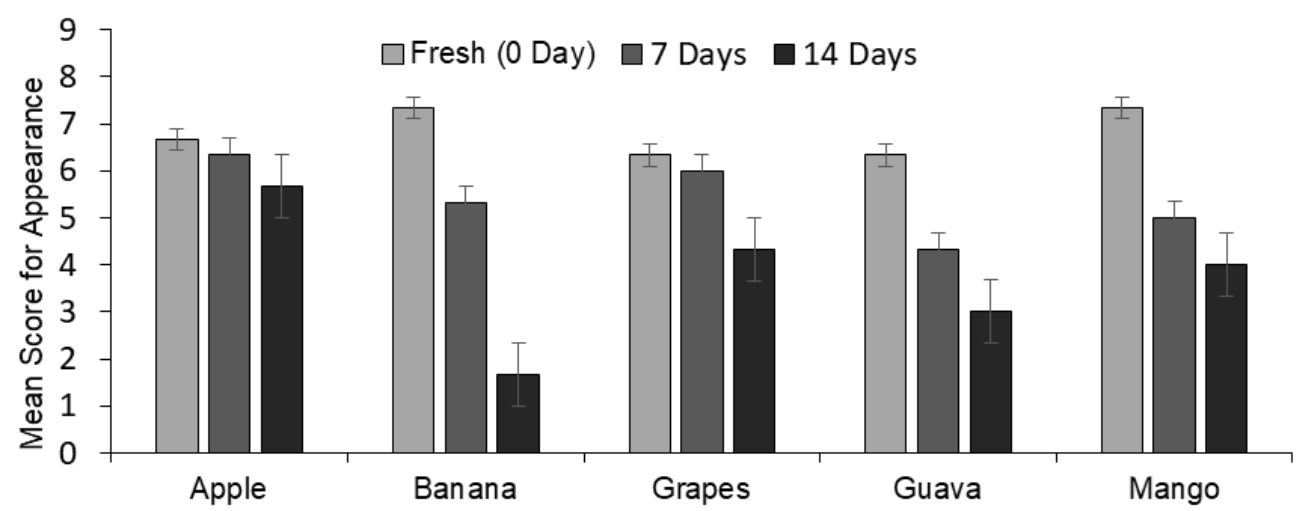

Figure 7. Mean score for appearance of apple, banana, grapes, guava and mango fruits during 14 days storage at ambient room temperature. The bars represent the standard errors of means

\subsubsection{Odour}

Significant changes were observed in the odour of all fruits over two weeks storage period (Table 1). A gradual decrease in the mean score for odour of all fruits was recorded during the storage time (Figure 8). Similar results were obtained by ${ }^{[53]}$ who noted changes in some flesh volatiles muskmelons during storage which were responsible for development of unpleasant odour.

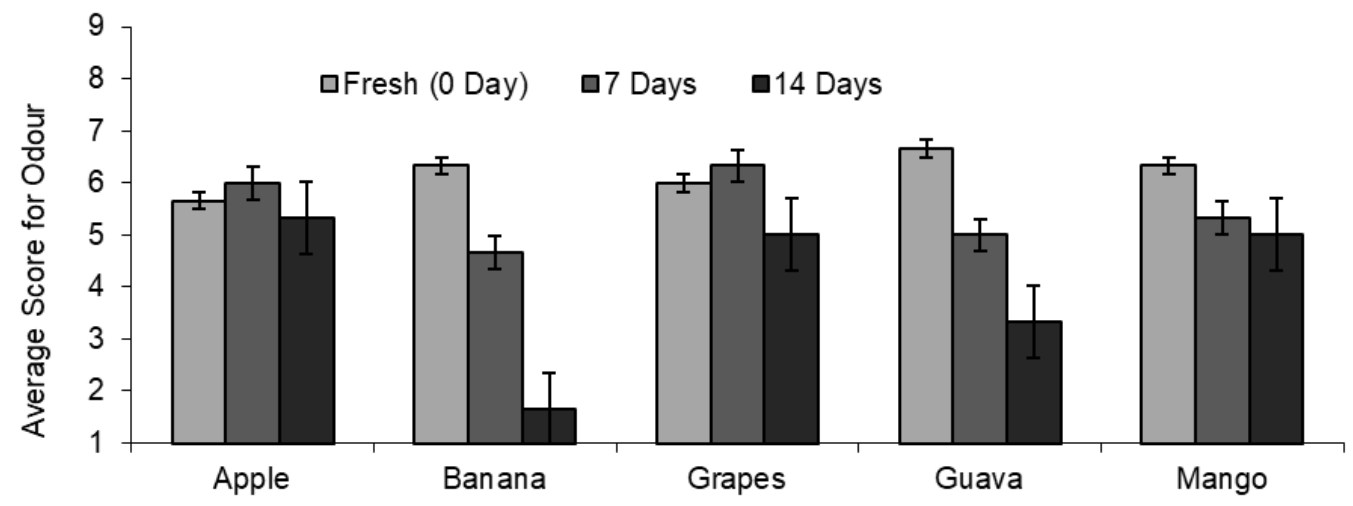

Figure 8. Mean score for odour of apple, banana, grapes, guava and mango fruits during 14 days storage at ambient room temperature. The bars represent the standard errors of means

\subsubsection{Taste}

Both the storage time and fruit type significantly $(P<0.05)$ affected the taste of fruits, however, their interaction was found non-significant $(P>0.05)$ (Table 1). After the storage period, the lowest average score was recorded for mango, whereas the highest score was reported for apple and guava fruits (Figure 9). After the 14 days storage, some of the fruits (banana, guava and mango fruits) showed decaying symptoms rendering it unfit for further evaluation. The results of our findings are in agreement with the work done by ${ }^{[7]}$ and ${ }^{[54]}$ who reported a significant decreasing trend in taste of apples or mangoes with the passage of storage time. 


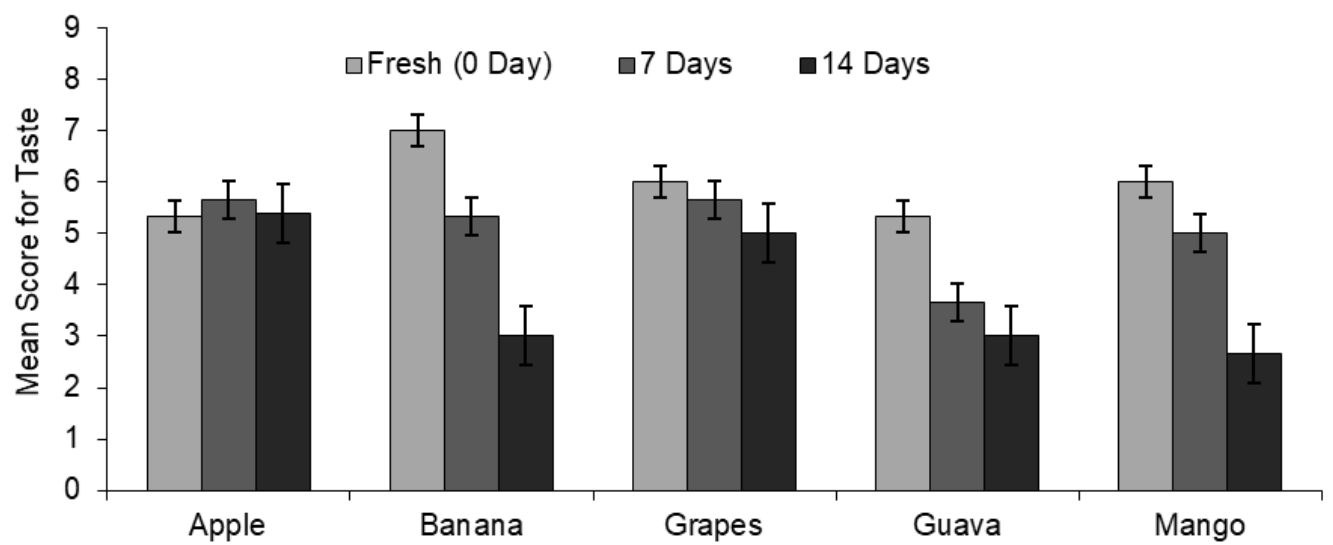

Figure 9. Mean score for taste of apple, banana, grape, guava and mango fruits during 14 days storage at ambient room temperature. The bars represent the standard errors of means

\subsubsection{Texture}

The results regarding texture (Figure 10) of selected fruits showed that apple retained the best texture whereas banana and guava showed the worst texture after 14 days storage. Our findings are fairly supported by the work done by ${ }^{[4,7,55]}$ who reported a declining trend in the texture of fruits with storage time.

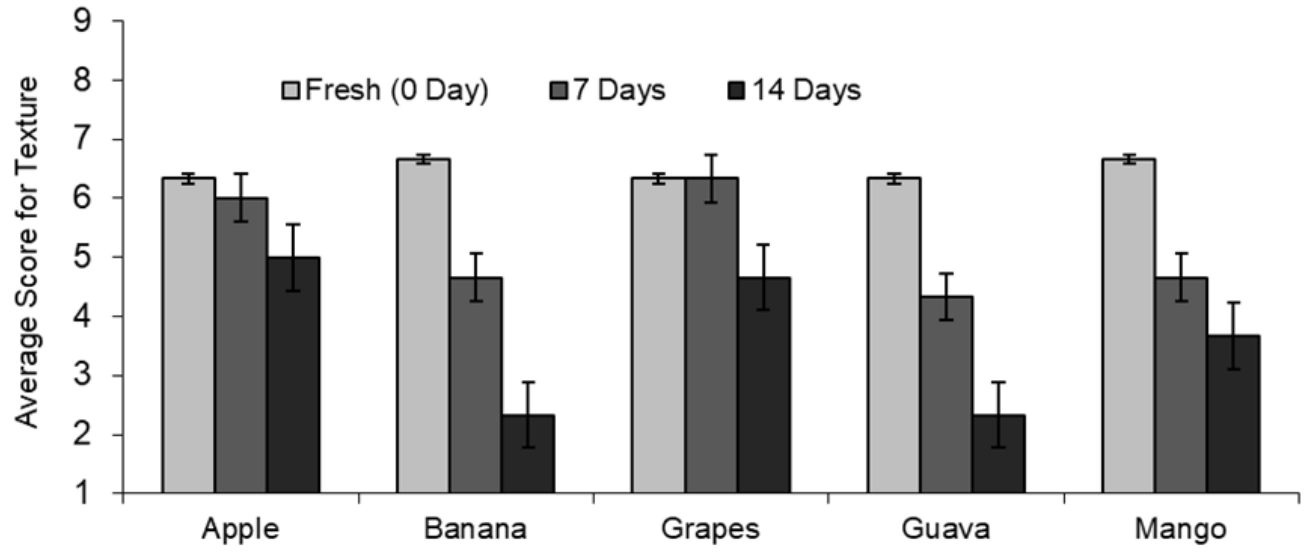

Figure 10. Mean score for texture of apple, banana, grape, guava and mango fruits during 14 days storage at ambient room temperature. The bars represent the standard errors of means

\subsubsection{Overall acceptability}

The mean scores for overall acceptability of apple, banana, grapes, guava and mango showed a decreasing trend with the passage of storage time (Figure 11). The highest decrease in score was observed for banana followed by mango and the lowest decrease was observed for apple. It was observed that fully ripe banana, mango and guava fruits showed decaying symptoms and visible mould growth after 5 days. However, the storage time (14 days) did not have any appreciable effect on the overall acceptability of apple and grapes. The highest acceptability of apple and grapes after 14 days storage may be attributed to their good flavour, texture and appearance ${ }^{[4,55,56]}$. 


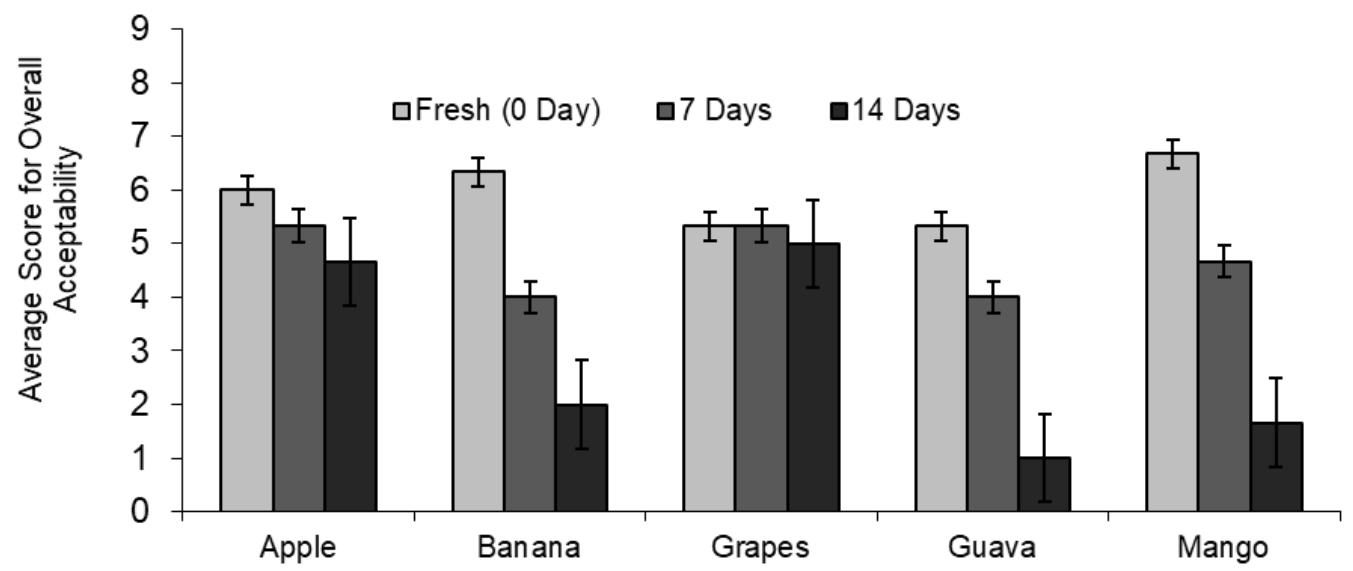

Figure 11. Mean score for overall acceptability of apple, banana, grape, guava and mango fruits during 14 days storage at ambient room temperature. The bars represent the standard errors of means 
Table 1. Analysis of variance of moisture content, $\mathbf{a}_{w}$, vitamin C, TBCs, TFCs, appearance, odour, taste, texture and overall acceptability of different fruits stored for 14 days under ambient room conditions

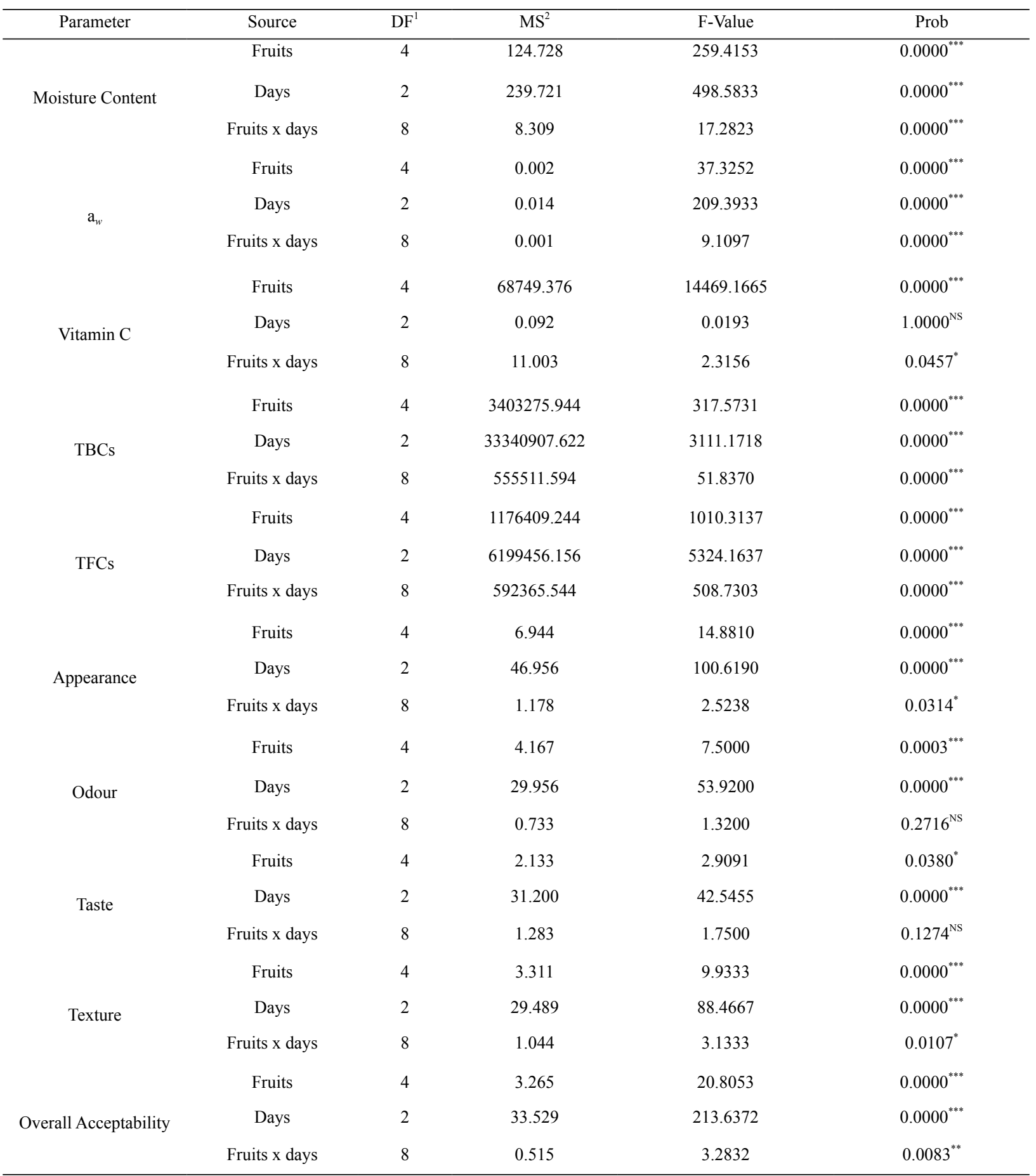

${ }^{* * * *}$ Significant $P<0.001,{ }^{* *}$ Significant $P<0.01$, , Significant $P<0.05,{ }^{\text {NS }}$ Non-Significant

${ }^{1} \mathrm{DF}=$ Degree of freedom, ${ }^{2} \mathrm{MS}=$ Mean square

\section{Conclusions}

From the present study, it was concluded that storage conditions and duration of storage time had a significant influence on the shelf life, nutritional quality and overall acceptability of fresh fruits. Moisture content, $\mathrm{a}_{w}$ and vitamin $\mathrm{C}$ content showed a decreasing trend whereas microbial counts showed an increasing trend with storage time. Sensory quality was also gradually decreased with the passage of storage time. Among the selected fruits, apple had the longest shelf life 
and was slightly influenced in term of chemical, microbiological and sensory quality. It is recommended that fresh fruits should be stored at low temperature in hygienic conditions with proper relative humidity.

\section{Acknowledgement}

The authors are profoundly indebted to Dr. Abdur Rafi, Department of Plant Pathology, the University of Agriculture, Peshawar for his technical assistance in the microbiological studies.

\section{References}

[1] Hai, L.R. Health benefits of fruit and vegetables are from additive and synergistic combinations of phytochemicals. Amer. J. Clinic. Nutr. 2003; 78: 517S-520S.

[2] Willett, W.C. Diet, nutrition, and avoidable cancer. Environ. Health Perspect. 1995; 103: 165-170.

[3] Kaur, C., H.C. Kapoor. Antioxidants in fruits and vegetables-the millennium's health. Int. J. Food Sci. Tech. 2001; 36: 703-725.

[4] Rathore, H.A., T. Masud, S. Sammi, A.H. Soomro. Effect of storage on physicochemical composition and sensory properties of mango (Magnifera indica L.,) variety Dosehari. Pak. J. Nutr. 2007; 6: 143-148.

[5] Kumar, P.S., V.R. Sagar, U. Singh. Effect of tray load on drying kinetics of mango, guava and aonla. J. Sci. Ind. Res. 2006; 65: 659-664.

[6] USDARS (United States Department of Agriculture Research Service) 2010. USDA National Nutrient Database for Standard Reference, Release 23. Nutrient Data Laboratory. Retrieved 2013.

[7] Hayat, I., T. Masud, H.A. Rathore. Effect of coating and wrapping materials on the shelf life of apple (Malus domestica cv. Borkh). Int. J. Food Safety. 2005; 5: 24-34.

[8] Hussain, T. Food composition table for Pakistan. Government of Pakistan. Ministry of Planning and Development Islamabad. 2001. p. 28.

[9] Adrees, M., M. Younis, U. Farooq, K. Hussain. Nutritional quality evaluation of different guava varieties. Pak. J. Agric. Sci. 2010; 47: 1-4.

[10] Shah, F.H. Food Compendium. Pakistan Council of Science and Industrial Research Publications. Lahore, Pakistan; 1988.

[11] Saltreit, M.E. Physical and physiological changes in minimally processed fruits and vegetables. In: Tomas-Barberan, F.A. ed. Phytochemistry of fruit and vegetables. Oxford Univ. Press, UK. 1996. p. 205-220.

[12] Alzamora, S.M., M.S. Tapia, A. Argaiz, J. Welli. Application of combined methods technology in minimally processed fruits. Food Res. Int. 1993; 26: 125-130.

[13] Soliva-Fortuny, R.C., O. Martin-Belloso. New advances in extending the shelf-life of fresh-cut fruits: a review. Trends Food Sci. Tech. 2003; 14: 341-353.

[14] Kader, A.A. Influence of preharvest and postharvest environment on nutritional composition of fruits and vegetables. In: B. Quebedeaux, F.A. Bliss. (eds.) Horticulture and human health: Contributions of fruits and vegetables. PrenticeHall, Englewood Cliffs, New Jersey, and Amererican Society of Horticultural Sciences Alexandria and Virginia. 1988. p.18-32.

[15] Parviainen, M.T., Nyyssonen. Ascorbic acid. In: Leenheer, A.P.D., W.E. Lambert, H. Nelis. (eds.) Modern chromatographic analysis of vitamins. Marcel Dekker, New York; 1992.

[16] Michalczuk, L. Proceedings of the international symposium on effect of preharvest and post-harvest factors on storage of fruits. Acta Hort. 1999; 485: 1-411.

[17] Alam, S., H.U. Shah, H. Khan, N. Magan. The effect of substrate, season and agroecological zone on mycoflora and aflatoxin contamination of poultry feed from Khyber Pakhtunkhwa, Pakistan. Mycopathologia. 2012; 174: $341-349$.

[18] Shah, H.U., T.J. Simpson, S. Alam, K.F. Khattak, S. Parveen. Mould incidence and mycotoxin contamination in maize kernels from Swat Valley, North West Frontier Province of Pakistan. Food Chem. Toxicol. 2010; 48: 1111-1116.

[19] Pitt, J.I. and A.D. Hocking. Fungi and Food Spoilage. 3th ed. Blackie Academic \& Professional, London, UK; 1997.

[20] Samson, R.A., J. Houbraken, U. Thrane, J.C. Frisvad, B. Anderson. Food and indoor fungi. CBSKNAW Biodiversity Center, Utrecht; 2010.

[21] Andrew. Manual of food quality control. Food and Agricultural Organization of United Nation, Rome. 1992; 7: 302303.

[22] Ranganna, S. Manual of analysis of fruits and vegetables products. Tata McGrawHill Pub. Company Ltd. New Delhi, India; 1978.

[23] Kiltic, D., G. Favetto, J. Chirife, S. Resnik. Measurement of water activity in the intermediate moisture range with Novasina Thermoconstanter humidity meter. Lebensmittel Wissenschaft und-Technologie. 1986; 19: $297-301$.

[24] Alam, S., H.U. Shah, N. Magan. Water availability affects extracellular hydrolytic enzymes production by Aspergillus 
flavus and Aspergillus parasiticus. World Mycotoxin J. 2009; 2: 313-322.

[25] Ruck, J.A. Chemical methods for analysis of fruit and vegetables. Department of Agriculture, Canada. 1963. p.1154.

[26] Larmond, E. Laboratory methods of sensory evaluation of food. Publication 1637. Department of Agriculture, Ottawa, Canada; 1977.

[27] Steel, R.G.D., J.H. Torrie. Principles and procedures of statistics: A biometrical approach ( $3^{\text {rd }}$ Ed). McGraw-Hill Inc, New York; 1977.

[28] Fatima, N., H. Batool, V. Sultana, J. Ara, S. Ehteshamul-Haque. Prevalence of post-harvest rot of vegetables and fruits in Karachi, Pakistan. Pak. J. Bot. 2009; 41. 3185-3190.

[29] Udoh, I.P., C.I. Eleazar, B.O. Ogeneh, M.E. Ohanu. Studies on fungi responsible for the spoilage/deterioration of some edible fruits and vegetables. Adv. Microbiol. 2015; 5: 285-290.

[30] Mailafia, S., R.O. God'spower, H.O.K. Olabode, R. Osanupin. Isolation and identification of fungi associated with spoilt fruits vended in Gwagwalada market. Abuja, Nigeria. Vet. World. 2017; 10: 393-397.

[31] Singh, D., R.R. Sharma. Postharvest diseases of fruit and vegetables and their management. In: Prasad, D., editor. Sustainable Pest Management. Daya Publishing House, New Delhi, India; 2007.

[32] Droby, S. Improving quality and safety of fresh fruits and vegetables after harvest by the use of biocontrol agents and natural materials. Acta Hort. 2006; 709: 45-51.

[33] Aujla, K. M., N. A. Shah, M. Ishaq and A. Farooq. Post-harvest losses and marketing of grapesin Pakistan. Sarhad J. Agric. 2011; 27: 485-490.

[34] Zhu, S.J. Non-chemical approaches to decay control in postharvest fruit. In: B. Noureddine and S. Norio Ed. Advances in Postharvest Technologies for Horticultural Crops. Research Signpost, Trivandrum, India. 2006. p. 297-313.

[35] Nagy, H.A., L.A.A. Moussa. Influence of gamma-radiation on mycotoxin producing moulds and mycotoxins in fruits. Food Control. 2002; 13: 281-288.

[36] Sonali, P., J. Pradnya. Microbiological analysis of fresh fruits and vegetables and effect of anti-microbial agents on microbial load. Ph.D. Thesis, University of Mumbai, India; 2008.

[37] Trevor, S. Microbial food safety: An emerging challenge for small scale growers. Small Farm News. 1997; June-July 7-10.

[38] Wiley, R.C. Minimally processed refrigerated fruits and vegetables. Chapman and Hall, London, UK; 1994.

[39] Watada, A.E., L. Qi. Quality of fresh cut produce. Postharvest Biol. Technol. 1999; 15: 201-205.

[40] Bartz, J.A., J.K. Brecht. Postharvest physiology and pathology of vegetables, 2nd (eds.) Marcel Dekker, New York; 2001.

[41] FAO (Food and Agricultural Organization). Prevention of post-harvest food losses: fruits, vegetables and root crops-a training manual. FAO Training Series. Rome. 1989; 17/2.

[42] Cappellini, R.A., M.J. Ceponis. Postharvest losses in fresh fruits and vegetables. In: Moline, H.E. (eds.) Postharvest pathology of fruits and vegetables: postharvest losses in perishable crops. University of California Bulletin 1914. 1984. p. 24-30.

[43] Li, R., H. Zhang, W. Liu, X. Zheng. Biocontrol of postharvest gray and blue mold decay of apples with Rhodotorula mucilaginosa and possible mechanisms of action. Int. J. Food Microbiol. 2011;146: 151-156.

[44] Bourne, M.C. Effect of water activity on texture profile parameters of apple flesh. J. Text. Std. 1986; 17: 331-340.

[45] Azeredo, H.M.C., F.B.S. deAraujo, D.S. deGarruti, A.A.M. Queiroz, G.A.S. Pinto. Stability of mango cubes preserved by hurdle technology. Ciencia e Agrotecnologia. 2005; 29: 377-381.

[46] Vega-Mercado, H. and G.V. Barbose-Canovas. Prediction of water activity in food systems. A review on theoretical models. Revista Espanola de Ciencia y Technologia de Alimentos. 1994; 34: 368-388.

[47] Magan, N. and M. Olsen. Mycotoxins in food: detection and control. Woodhead Publishing, Cambridge, England. ; 2004.

[48] Fenech, M., Amaya, I., Valpuesta, V. and Botella, M.A. Vitamin C content in fruits: Biosynthesis and regulation. Front. Plant Sci. 2018; 9.

[49] Gautier, H., V. Diakou-Verdin, C. Benard, M. Reich, M. Buret, F. Bourgaud, J. L. Poessel, C. Caris-Veyrat, M. Genard. How does tomato quality (sugar, acid, and nutritional quality) vary with ripening stage, temperature, and irradiance? $J$. Agric. Food Chem. 2008; 56: 1241-1250.

[50] Blazek, J., I. Hlusickova, A. Varga. Changes in quality characteristics of Golden Delicious apples under different storage conditions and correlations between them. Hort. Sci. 2003; 30: 81-89.

[51] Ali, M.A., H. Raza, M.A. Khan, M. Hussain. Effect of different periods of ambient storage on chemical composition of apple fruit. Int. J. Agric. Biol. 2004; 6: 568-571.

[52] Jamba, A., B. Carabulea. Tehnologia pastrarii si industrializarii produselor horticole, ed. Cartea Moldovei, Chisinau; 2002.

[53] Miyazaki, T., M. Ookubo. Effects of maturity and postharvest techniques on keeping quality of melons. J. Jap. Soc. 
Hort. Sci. 1989; 58: 361-368.

[54] Raje, L., S. Sherlekar, K. Ramakrishman, V.C. Malshe, G. Subbulakshmi. Postharvest preservation of mangoes by controlled chemical release agents and adsorbent. Acta Hort. 1997; 455: 622-628. 